\title{
Choice feeding for laying guinea fowl parent flocks in a free-range system
}

\author{
M. Frątczak ${ }^{1,2}$, D. Józefiak ${ }^{1}$ and A. Rutkowski ${ }^{1}$ \\ The August Cieszkowski Agricultural University of Poznań, \\ Department of Animal Nutrition and Feed Management \\ Wotyńska 33, 60-637 Poznań, Poland
}

\begin{abstract}
The productive parameters of parent flocks of guinea fowls kept during the reproduction period in open-air aviaries were compared. The birds were divided randomly into three groups, each comprising seven replicates, twelve birds per replicate. The first group was fed a complete diet, while the birds in the second group were given, in separate feeders, maize grain and high protein and mineral-vitamin components. In the third group, maize was substituted by wheat grain. All feeds throughout the experiment were fed ad libitum. Daily intake of metabolizable energy was very uniform in all groups in which the basic source of energy was maize, irrespective of the way it was fed. Daily protein intake was similar in all groups. Guinea fowls fed complete diets had higher laying rates, utilized feed better for egg production and laid eggs of higher weight. The results indicate that the applied feeding system had an influence on production parameters during the reproduction period of guinea fowls.
\end{abstract}

KEYWORDS: guinea fowl, choice feeding, free range, maize, wheat

\section{INTRODUCTION}

At present, the majority of laying poultry is fed complete diets because it is generally believed that this is the best and the simplest method of optimally balancing diets for birds (Stadelman, 1995). However, several other feeding systems are known, which are close to natural feeding behaviour, including socalled choice feeding (Henuk and Dingle, 2002). This system allows each bird individual selection of diet by free choice of individual feed constituents by providing them in separate feeders (Karunajeewa and Tham, 1984; Forbes, 1995).

\footnotetext{
${ }^{2}$ The author is a beneficiary of The Foundation of Polish Science

${ }^{1}$ Corresponding authors: e-mail: maciej.fratczak@wp.pl; rutkowski@jay.au.poznan.pl
} 
In the available literature, no data was found concerning a choice-feeding system applied to guinea fowls in the laying period.

\section{MATERIAL AND METHODS}

A parent stock of ISA ESSOR guinea fowls was divided into 21 flocks of 10 females and 2 males in each. Three experimental groups were established, each with seven replicates, kept in outdoor aviaries of $20 \mathrm{~m}^{2}$ with permanent access to water and feed. Group I was fed a complete mixture with a composition corresponding to birds' requirements recommended by the producer of the breeding material. Group II was fed in the choice-feeding system; maize grain and a mixture of solvent-extracted oilmeals supplemented with mineral-vitamin components were provided in two separate feeders. Group III was fed like group II, the only difference was that maize was replaced by wheat grain. All components of the experimental mixtures were ground and fed ad libitum.

Daily feed consumption was measured and laid eggs collected and weighed. Production parameters of laying guinea fowls at the time when the mean laying rate reached the value of $10 \%$ was compared.

One-way analysis of variance was done with use of the Statgraphics Plus ver. 6.0 software package.

\section{RESULTS AND DISCUSSION}

The highest mean laying rate was achieved in the flocks of guinea fowls fed a complete mixture. The experimental birds reached peak laying in the eighth week when their mean weekly laying attained $72.4 \%$. Birds fed in the choicefeeding system achieved a lower mean laying rate, as confirmed by statistical analysis. Birds from these groups reached peaks of their laying slightly earlier; birds from group II in the $6^{\text {th }}$ week $(65.9 \%)$, while those from group III, in the $5^{\text {th }}$ week $(63.3 \%)$ and these peaks were characterized by lower values. The lowest total feed consumption was recorded in group III, while in groups I and II it was similar. This does not support the results obtained on laying hens by Leeson and Summers (1979) and Henul et al. (2000) who found that choice feeding results in lower feed consumption. The performed experiment confirmed significantly more favourable feed utilization for egg production in the group of birds fed complete diets, allowing the conclusion that feeding guinea fowls complete diets was more economical. Mean daily intakes of metabolizable energy in groups I and II were similar. This supports the view that birds are perfectly capable of 
selecting the amount of ingested energy and that energy requirements are an important factor affecting consumption. Similar conclusions were drawn by Hill et al. (1956) from an experiment on chickens. A lower energy intake was found in group III, where wheat grain was used, which indicates that energy intake can

Table 1. Performance results

\begin{tabular}{lccc}
\hline & \multicolumn{3}{c}{ Dietary treatment } \\
\cline { 2 - 4 } Item & control & $\begin{array}{c}\text { choice-feed } \\
\text { maize }\end{array}$ & wheat \\
\hline Laying rate, \% - $^{-}$ & $58.1^{\mathrm{c}}$ & $52.1^{\mathrm{b}}$ & $47.0^{\mathrm{a}}$ \\
Daily feed consumption, g & $125.6^{\mathrm{ab}}$ & $129.6^{\mathrm{b}}$ & $120.0^{\mathrm{a}}$ \\
Feed/1 egg, g & $282.4^{\mathrm{a}}$ & $326.3^{\mathrm{b}}$ & $356.6^{\mathrm{c}}$ \\
Feed/kg of eggs, g & $5260^{\mathrm{a}}$ & $6330^{\mathrm{b}}$ & $6870^{\mathrm{c}}$ \\
Grain consumption per day, g & 81.6 & 79.8 & $77.3^{\mathrm{a}}$ \\
Consumption of protein+min.-vit. components, g & $44.0^{\mathrm{a}}$ & $49.8^{\mathrm{b}}$ & $42.5^{\mathrm{a}}$ \\
Consumption of ME/day, kcal & $337.0^{\mathrm{b}}$ & $338.0^{\mathrm{b}}$ & $302.0^{\mathrm{a}}$ \\
Crude protein /day, g & $21.4^{\mathrm{a}}$ & $22.8^{\mathrm{a}}$ & $22.3^{\mathrm{a}}$ \\
ME: crude protein ratio & $15.7^{\mathrm{a}}$ & $14.8^{\mathrm{a}}$ & $13.5^{\mathrm{a}}$ \\
Ca consumption/day, g & $4.0^{\mathrm{ab}}$ & $4.5^{\mathrm{b}}$ & $3.8^{\mathrm{a}}$ \\
Ca consumption/1 egg, g & $9.1^{\mathrm{a}}$ & $11.3^{\mathrm{ab}}$ & $11.1^{\mathrm{ab}}$ \\
Ratio of grain: protein-min.-vit components & $1.8^{\mathrm{b}}$ & $1.6^{\mathrm{a}}$ & $1.8^{\mathrm{b}}$ \\
Mean egg weight, g & $53.6^{\mathrm{b}}$ & $52.0^{\mathrm{ab}}$ & $50.9^{\mathrm{a}}$ \\
Mean egg number/1 layer & $86^{\mathrm{c}}$ & $78^{\mathrm{b}}$ & $70^{\mathrm{a}}$ \\
Mortality, \% & $5.7^{\mathrm{a}}$ & $10.0^{\mathrm{a}}$ & $10.0^{\mathrm{a}}$ \\
Body weight gain, g & $541^{\mathrm{a}}$ & $590^{\mathrm{a}}$ & $600^{\mathrm{a}}$ \\
\hline
\end{tabular}

means in rows with different letters are significantly different at $\mathrm{P} \leq 0.05$

be influenced by its source. Daily crude protein intake was similar in all groups, supporting the view expressed by Holcombe et al. (1976) about the ability of birds to take the required quantity of protein themselves. It appears that the source of protein is not as significant for the level of intake as the source of energy. Only differences in the quantity and weight of laid eggs were confirmed statistically, with guinea fowls fed complete diets laying the highest number of eggs. A considerable increase in body weight gains observed in this study supports the view about the considerable predisposition of laying guinea fowl to excessive fattening (Hastings- Belshaw, 1985; Coz-Douin, 1993). The content of the soluble dietary fibre fraction in wheat is higher than in maize. This may suggest that the worse performance results in birds fed wheat-based diets were caused by the higher amount of these carbohydrates. However, ileal viscosity as well as dietary fibre composition were not estimated in the experiment. 


\section{REFERENCES}

Coz-Douin J., 1993. L'elevage de la Pintade. Editions du Point Veterinaire 25

Forbes J.M., Covasa M., 1995. Application of diet selection by poultry with particular reference to whole cereals. World Poultry Sci. J. 51, 149-165

Hastings Belshaw R.W., 1985. Guinea Fowl of the World. Nimrod Book Services, Hampshire

Henuk Y.L, Dingle J.G., 2002. Practical and economical advantages of choice feeding systems for laying poultry. World Poultry Sci. J. 58, 199-208

Henuk Y.L., Thwaites C.J., Hill M.K., Dingle J.G., 2000. The effect of temperature on response of laying hens to choice feeding in a single feeder. Proceedings of the Australian Poultry Science Symposium, University of Sydney, pp. 117-120

Hill F.W., Anderson D.L., Dansky L.M., 1956. Studies of the energy requirements of chickens. Poultry Sci. 35, 54-59

Holcombe D.J., Roland D.A., Harms R.H., 1976. The ability of hens to regulate protein intake when offered a choice of diets containing different levels of protein. Poultry Sci. 55, 1731-1737

Karunajeewa H., Tham S.H., 1984. Choice feeding of the replacement pullet on whole grains and a subsequent performance on laying diets. Brit. Poultry Sci. 25, 99-109

Leeson S., Summers J.D., 1979. Dietary self selection by layers. Poultry Sci. 58, 646-651

Stadelman W.J., 1995. Egg Production Practices. Egg Science and Technology. $4^{\text {th }}$ Edition. Food Press Products, New York, pp. 9-37

\section{STRESZCZENIE}

\section{System wolnego wyboru $w$ żywieniu stada rodzicielskiego perlic w warunkach wolno- wybiegowych}

Celem doświadczenia było porównanie wyników produkcyjnych stad rodzicielskich perlic utrzymywanych w wolierach zewnętrznych. Ptaki podzielono losowo na trzy grupy, po siedem powtórzeń każda; powtórzenie składało się z 12 ptaków. Pierwsza grupa otrzymywała mieszankę pełnoporcjową; grupa druga śrutowane ziarno kukurydzy, a w osobnym karmidle mieszankę białkowo-mineralno-witaminową; w grupie trzeciej ziarno kukurydzy zastępowano śrutowanym ziarnem pszenicy. Diety podawano do woli.

Średnie dzienne pobranie energii metabolicznej było wyrównane w grupach otrzymujących mieszankę pełnoporcjową i kukurydzę jako składnik energetyczny. Pobranie białka ogólnego było wyrównane we wszystkich grupach. Perlice, którym podawano mieszankę pełnoporcjową znosiły więcej jaj i lepiej wykorzystywały paszę. Na podstawie przeprowadzonego doświadczenia można stwierdzić, że system podawania paszy ma istotne znaczenie w produkcji jaj wylęgowych perlic. 